$\delta$ ELT $\Delta$

Jurnal Ilmiah Pendidikan Matematika

p.ISSN: 2303 -3983 e.ISSN:2548-3994

Vol. 8 No. 1 Januari 2020 Hal $41-60$

DOI: http://dx.doi.org/10.31941/delta.v8i1.953

\title{
PENGEMBANGAN MEDIA PUZZLE UNTUK PEMBUKTIAN TEOREMA PYTHAGORAS
}

\author{
Mas'ud Rifai, Erlina Prihatnani \\ Pasca Sarjana Universitas Negeri Semarang, Universitas Kristen Satya Wacana \\ 202013051@student.uksw.edu
}

Received : 17/01/2020

Accepted : 28/01/2020

Published : 31/01/2020

\begin{abstract}
This research aims to develop a learning media that is valid, practical and effective in building an understanding of the Pythagorean proposition. The results of this study are learning media products in the form of PuPPy puzzles (Pythagorean Proof Puzzles). The development model used is ADDIE (Analyze, Design, Develop, Implementation, Evaluation). The instruments used were media validation sheets, practical sheets, pretest, posttest, and student opinion sheets. This media was tested on 28 students of class VIII D of SMP Negeri 2 Tuntang, Semarang Regency. Validity test produced a percentage of 94.61 (very good) from media experts and $91.33 \%$ (very good) from material experts. The practicality analysis analysis by the teacher produced a percentage of $95.5 \%$ categorized very well. In addition, the effectiveness test using N-Gain gained an increase of 0.71 which was categorized as a height increase. Based on these results it can be concluded that the PuPPy media is a valid, practical and effective media to help students develop an understanding of the Pythagorean proposition.
\end{abstract}

Keywords: earning media, puzzle, Pythagorean theorem, PuPPy

\begin{abstract}
Abstrak
Penelitian ini bertujuan mengembangkan media pembelajaran yang valid, praktis dan efektif dalam membangun pemahaman tentang dalil Pythagoras. Hasil Penelitian ini adalah produk media pembelajaran berupa puzzle PuPPy (Puzzle Pembuktian Pythagoras). Model pengembangan yang digunakan adalah ADDIE (Analyze, Design, Develop, Implementation, Evaluation). Instrumen yang digunakan adalah lembar validasi media, lembar kepraktisan, pretest, posttest, dan lembar pendapat siswa. Media ini diujicobakan kepada 28 orang siswa kelas VIII D SMP Negeri 2 Tuntang Kabupaten Semarang. Uji kevalidan menghasilkan persentase 94,61 (sangat baik) dari ahli media dan 91,33\% (sangat baik) dari ahli materi. Adapun analisis uji kepraktisan oleh guru menghasilkan persentase sebesar 95,5\% dikategorikan sangat baik. Selain itu uji keefektifan menggunakan NGain memperoleh peningkatan sebesar 0,71 yang dikategorikan peningkatan tinggi. Berdasarkan hasil tersebut dapat disimpulkan bahwa media PuPPy merupakan media yang valid, praktis dan efektif untuk membantu siswa mebangun pemahaman tentang dalil Pythagoras.
\end{abstract}

Kata Kunci: media pembelajaran, puzzle, teorema Pythagoras, PuPPy

\section{Pendahuluan}

Belajar matematika pada dasarnya adalah belajar berpikir atau belajar memecahkan masalah. Menurut Dogde dan Colker (Khasanah, 2013), matematika adalah kemampuan untuk menciptakan hubungan-hubungan dan menjadi pemikiran. Ketika belajar matematika, peserta didik perlu diberi kesempatan untuk menyelidiki, mengorganisasikan benda-benda konkret sebelum peserta didik dapat menggunakan simbol-simbol yang telah dikenalnya secara abstrak. Bruner menyebutkan bahwa belajar matematika tidak lepas dari belajar konsep 
(Heruman, 2013). Konsep tersebut bukan diterima begitu saja namun dikonstruksi. Hal itu dikarenakan belajar tidak sekedar menerima, namun belajar merupakan proses mengkonstruksi konsep-konsep yang dipelajari. Suparno (1997: 29) mengemukakan bahwa pengetahuan tidak dapat ditransfer begitu saja dari seseorang kepada yang lain, tetapi harus diinterprestasikan sendiri oleh masing-masing orang. Oleh karena itu, siswa harus lebih banyak diberi kesempatan untuk mengkontruksi konsep mereka melalui interaksi mereka dengan objek, fenomena, pengalaman dan lingkungan mereka. Aktivitas pembelajaran yang menandai adanya proses konstruksi pengetahuan oleh siswa diantaranya adanya kegiatan 1) merumuskan pertanyaan secara kolaboratif, 2) menjelaskan fenomena yang dilihat, 3) berfikir kritis tentang isu-isu yang bersifat kompleks, dan 4) mengatasi masalah yang sedang dihadapi (Pribadi, 2009).

Setiap konsep dalam matematika berkaitan satu dengan yang lain. Selain itu suatu konsep bisa menjadi prasyarat bagi konsep yang lain. Penguasaan suatu konsep diperlukan untuk mempelajari konsep lainnya. Salah satu konsep dalam matematika adalah teorema Pythagoras.

Teorema Pythagoras menyatakan bahwa pada setiap segitiga siku-siku berlaku kuadrat panjang sisi miring (hipotenusa) sama dengan jumlah kuadrat panjang sisi-sisi siku-sikunya (Husain, 2005). Teorema ini ditemukan oleh Pythagoras von Samos, seorang ahli matematika berkebangsaan Yunani yang hidup pada abad keenam Masehi dan berkesempatan memperdalam ilmunya di Babilonia (Adinawan dan Sugiyono, 2008). Teorema ini muncul sekitar 4000 tahun yang lalu, dimana orang Babilonia dan orang Cina menyadari fakta bahwa sebuah segitiga dengan sisi-sisi 3, 4, dan 5 satuan panjang menjadi segitiga siku-siku (Victor, 2009). Konsep ini dimanfaatkan untuk membangun konstruksi sudut siku-siku, dan merancang konstruksi segitiga siku-siku dengan membagi panjang sebuah tali menjadi dua belas bagian yang memiliki ukuran sama, sehingga satu sisi segitiga ada tiga, sisi kedua empat, dan sisi ketiga ada lima bagian. Penggunaan teorema Pythagoras dapat untuk menentukan panjang sebuah sisi pada segitiga siku-siku jika panjang dua sisi yang lain diketahui

Teorema Pythagoras diajarkan secara formal pertama kali pada siswa SMP/MTs kelas VIII semester 1, dengan Standar Kompetensi yaitu: "Menggunakan Teorema Pythagoras dalam Pemecahan Masalah" dan Kompetensi Dasar, "Menggunakan Teorema Pythagoras untuk Menentukan Panjang Sisi-sisi Segitiga Siku-siku dan Memecahkan Masalah pada Bangun Datar yang Berkaitan dengan Teorema Pythagoras”. Terorema Pythagoras merupakan materi prasyarat untuk belajar materi lainnya seperti materi segitiga, lingkaran, garis singgung lingkaran, bangun ruang sisi lengkung dan lain-lain. Oleh karena itu siswa perlu untuk 
menguasai teorema Pythagoras. Meskipun demikian beberapa siswa SMP masih mengalami kesulitan pada materi ini.

Laporan hasil analisis ujian nasional tingkat SMP tahun 2014/2015 menyebut bahwa daya serap siswa akan materi ini sebesar 54,06\% untuk tingkat nasional, dimana Jawa Tengah hannya mencapai $45,57 \%$. Adapun daya serap siswa di Kabupaten Semarang akan materi ini sebesar 48,97\% (BSNP). Hal itu menunjukkan bahwa sebagian besar siswa SMP di daerah Jawa Tengah khususnya di Kabupaten Semarang belum menguasai Pythagoras.

Permasalahan yang sama juga terjadi pada siswa SMP Kristen 2 Salatiga. Kristianti (2016) dalam penelitiannya mengungkapkan bahwa kesalahan yang sering dilakukan siswa adalah kesalahan dalam penggunaan teorema Pythagoras. Siswa masih kesulitan untuk mencari suatu sisi dilakukan dengan menjumlah atau mengurangkan, jika mengurangkan mana yang harus dikurangi. Hal itu salah satunya dapat diakibatkan karena tidak diberikannya kesempatan siswa untuk menemukan rumus tersebut, sehingga daya ingat siswa akan rumus tersebut tidak maksimal. Siswa mengetahui rumus tersebut hanya dari mendengarkan penjelasan guru ataupun membaca di buku. Siswa tidak diberi kesempatan untuk membuktikan secara langsung. Teori Eddgar Dale (Dikti, 2014) mengatakan bahwa tingkat memorisasi terendah adalah membaca (hanya 10\%). Adapun pendengaran kata-kata, melihat gambar, melihat demonstrasi, berpartisipasi dalam diskusi berturut memiliki nilai $20 \%, 30 \%$, $50 \%$ dan $70 \%$. Capaian daya ingat terbesar bila siswa melakukan hal nyata dapat mencapai 90\%. Tingkatan tertinggi yakni melakukan hal nyata, oleh karena itu dalam pembelajaran siswa perlu diberikan kesempatan kepada siswa untuk dapat mengetahui asal rumus teorema Pythagoras. Bukti dari teroema Pythagoras sangat bermacam-macam, baik secara aljabar maupun geometris. Bukti-bukti tersebut dapat disajikan secara menarik sehingga mudah dipahami dan diingat siswa. Salah satu cara menyajikannya melalui media.

Media pembelajaran menurut Musfiqon (2012) adalah alat bantu berupa fisik maupun nonfisik yang sengaja digunakan sebagai perantara antara guru dan siswa dalam memahami materi pembelajaran agar lebih efektif dan efisien, sehingga materi materi pembelajaran lebih cepat diterima siswa dengan utuh serta menarik minat siswa untuk belajar lebih lanjut. Sejalan dengan hal itu, Rusman (2012) menyatakan bahwa media pembelajaran merupakan suatu teknologi pembawa pesan yang dapat digunakan untuk keperluan pembelajaran, dan juga sarana fisik untuk menyampaikan materi pembelajaran. Oleh karena itu perlu dikembangkan media pembelajaran yang valid, praktis dan efektif yang dapat digunakan sebagai media untuk belajar teorema Pythagoras. Media puzzle Pythagoras diharapkan tidak hanya bisa digunakan dalam pembelajaran di kelas, namun juga dapat digunakan siswa secara mandiri sebagai 
bentuk permainan edukasi yang dapat mempermudah siswa untuk mengkonstruksi teorema Pythagoras

\section{Metode Penelitian}

Penelitian ini merupakan penelitian pengembangan atau Research and Development (R\&D). Penelitian pengembangan adalah metode penelitian yang digunakan untuk menghasilkan produk tertentu dan menguji keefektifan produk tersebut (Sugiyono, 2012: 297). Subjek penelitian ini adalah siswa kelas VIII D SMP Negeri 2 Tuntang, Kabupaten Semarang yang sudah pernah menerima materi teorema Pythagoras. Model pengembangan penelitian ini menggunaan model ADDIE yang terdiri dari 5 tahap yaitu Analysis, Desain, Development, Implementation, Evaluation.

Instrumen penelitian ini terdiri lembar validasi, lembar kepraktisan dan instrumen pretest, posttest serta lembar respon siswa. Lembar validasi terdiri dari 2 aspek validasi yaitu media dan materi. Lembar ini digunakan untuk mengetahui kevalidan media pembelajaran. Adapun lembar kepraktisan diberikan untuk mengukur kepraktisan media pembelajaran ini, sedangkan instrumen pretest, posttest, dan lembar pendapat siswa untuk mengukur keefektifan penggunaan media. Data hasil belajar posttest siswa yang telah terkumpul kemudian dianalisis menggunakan $\mathrm{N}$-Gain guna mengetahui peningkatan pemahaman siswa akan materi teorema Pythagoras.

Data hasil validasi ahli media dan materi serta hasil uji kepraktisan berupa data kualitatif dan kuantitatif. Data kualitatif yang berupa kritik dan saran yang akan dijadikan sebagai pedoman untuk memperbaiki media pembelajaran yang dikembangkan. Adapun data kuantitatif yang diperoleh dari penilaian ahli materi dan ahli media akan dianalisis secara deskriptif. Kriteria skor penilaian ahli menggunakan skala dengan 5 interval, 1 (sangat kurang), 2 (kurang), 3 (cukup), 4 (baik) dan 5 (sangat baik). Rumus yang digunakan dalam perhitungan untuk memperoleh persentase kelayakan adalah rumus (i). Adapun dasar pengkategorian persentasi penilaian dikategorikan berdasar ketentuan pada Tabel 1.

$\mathrm{P}(\mathrm{s})=\mathrm{S} / \mathrm{N} \times 100 \% \quad \ldots$ (i)

Keterangan:

$\mathrm{P}(\mathrm{s})=$ persentase sub variabel

$\mathrm{S} \quad=$ jumlah skor tiap sub variabel

$\mathrm{N}=$ jumlah skor maksimum

Tabel 1. Kriteria Pengkategorian Hasil Penilaian Media Pembelajaran

\begin{tabular}{|l|l|l|}
\hline No & Interval & Kriteria \\
\hline
\end{tabular}




\begin{tabular}{|l|c|c|}
\hline 1 & $83 \% \leq$ skor $\leq 100 \%$ & Sangat Baik \\
2 & $62 \% \leq$ skor $<83 \%$ & Baik \\
3 & $41 \% \leq$ skor $<62 \%$ & Cukup Baik \\
\hline
\end{tabular}

Hasil dari lembar pendapat siswa berupa data kualitatif akan dideskripsikan guna menggambarkan respon siswa setelah menggunakan media pembelajaran. Hasil dari pretest dan posttest digunakan sebagai data untuk menguji keefektifan dihitung dengan rumus $\mathrm{N}$ Gain sebagai berikut.

$$
N \text { Gain }=\frac{\text { skor posttest }- \text { skor pretest }}{\text { skor maksimum }- \text { skor pretest }}
$$

N-Gain merupakan rata-rata peningkatan nilai siswa. Klasifikasi kategori N-Gain terdapat pada Tabel 2.

Tabel 2. Klasifikasi Kategori N-Gain

\begin{tabular}{|c|c|}
\hline Skor N-Gain & Kategori \\
\hline$G \geq 0,70$ & Peningkatan Tinggi \\
\hline $0,30 \leq G<0,70$ & Peningkatan Sedang \\
\hline$G<0,30$ & Peningkatan Rendah \\
\hline
\end{tabular}

Media dikatakan valid apabila hasil penilaian ahli materi dan media $\geq 62 \%$ (atau minimal masuk dalam kategori baik). Media ini termasuk praktis digunakan apabila hasil penilaian kepraktisan $\geq 62 \%$ (atau masuk dalam kategori baik) dan dikatakan efektif apabila minimal termasuk dalam peningkatan tinggi.

\section{Hasil dan Pembahasan}

Media pembelajaran matematika pada materi Pythagoras yang dikembangkan pada penelitian ini telah diterapkan sebagai media belajar bagi siswa kelas VIII SMP Negeri 2 Tuntang Kabupaten Semarang. Hasil penelitian dan pembahasan secara rinci dapat diuraikan sebagai berikut.
A. Analysis (Analisis)
a. Analisis Kebutuhan

Hasil observasi terhadap salah satu guru kelas VIII SMP Negeri 2 Tuntang Ibu Andri Irawati, pada tanggal 15 Maret 2017 menemukan fakta bahwa siswa kelas VII masih mengalami kesulitan pada materi Pythagoras. Siswa masih kesulitan untuk menentukan Pythagoras walaupun materi sudah pernah diajarkan. Selain itu siswa juga masih kesulitan untuk mencari suatu sisi dilakukan dengan menjumlah atau mengurangkan, jika mengurangkan mana yang harus dikurangi. Selama ini usaha guru untuk menangani kesulitan 
tersebut dengan cara memberikan penjelasan dan tanpa memberikan kesempatan kepada siswa untuk mengkonstruksi rumus Pythagoras. Hal ini juga diperkuat di hasil tes diagnostic yang diberikan kepada 28 siswa SMP Negri 2 Tuntang kelas VIII D. Soal yang diberikan sebanyak 30 dengan jawaban uraian, soal menyangkut tentang Pythagoras yang sudah pernah diajarkan. Hasil tes tersebut menunjukkan bahwa hannya 2 siswa tuntas sedangkan 27 siswa tidak mencapai kriteria nilai ketuntasan minimal KKM yaitu 70. Adapun rincian hasil tes diagnostic dapat dilihat pada Tabel 3.

Tabel 3. Hasil Tes Diagnostic Siswa Kelas VIII D

\begin{tabular}{|l|l|l|l|}
\hline Rentan & Kriteria & Jumlah Siswa & Persentase \\
\hline $0 \leq$ nilai $<70$ & Belum Tuntas & 26 & $92,86 \%$ \\
\hline $70 \leq$ nilai $\leq 100$ & Tuntas & 2 & $7,14 \%$ \\
\hline & Nilai Tertinggi $: 76,6$ \\
\hline & Nilai Terendah : 16,6 \\
\hline & Rata-rata $: 42,93$ \\
\hline
\end{tabular}

Pada Tabel 3 data 26 siswa (92,86\%) belum mencapai KKM. Ibu Andri menjelaskan bahwa siswa mengalami kesulitan dalam menghafal rumus Pythagoras. Siswa masih terbolakbalik dengan penempatan panjang sisi terpendek, sedang dan terpanjang. Bahkan siswa ada yang tidak mengerti sama sekali tentang teorema Pythagoras. Teorema Pythagoras sudah diajarkan sebelum dilakukan mengerjkan soal-soal yang diberikan. Pembelajaran yang diberikan guru selama ini dengan memberikan begitu saja teorema Pythagoras sehingga siswa tidak diberi kesempatan secara langsung untuk menemukan rumus, oleh karenanya siswa mengandalkan daya ingat.

b. Analisis Kinerja

Adapun hasil analisis kinerja dalam pengembangan media ini terbagi 3 kategori yang masing-masing diuraikan sebagai berikut.

1. Kurikulum (teorema Pythagoras)

Materi pembelajaran dalam penelitian ini adalah pokok teorema Pythagoras untuk siswa SMP kelas VIII semester 2 yang mengacu Lampiran Permendiknas No. 22 tahun 2006 mengenai Standar Isi. Standar Kompetensi dan Kompetensi Dasar materi Teorema Pythagoras.SMP Negeri 2 Tuntang Kabupaten Semarang menjalankan kurikulum KTSP. Materi teorema Pythagoras disampaikan sebelum materi lingkaran. Waktu yang disediakan untuk mempelajari materi ini yaitu $2 \times 4$ jam pelajaran yang artinya 8 jam pelajaran dengan setiap jam 40 menit. 
2. Karakteristik Siswa

Subjek penelitian ini adalah siswa kelas VIII SMP Negeri 2 Tuntang Kabupaten Semarang. Siswa tersebut rata-rata berumur 13 tahun. Menrut teori Piaget, siswa umur 13 tahun sudah memasuki tahap Operasi Formal. Piaget menemukan bahwa penggunaan operasi formal bergantung pada keakraban dengan daerah subjek tertentu. Apabila siswa akrab dengan suatu objek tertentu, lebih besar kemungkinan menggunakan operasi formal (Trianto,2015). Pada tahap ini individu melampaui dunia nyata, pengalaman konkret dan berfikir secara abstrak dan lebih logis (Suparno, 2001). Sebagai pemikiran yang abstrak, mereka mengembangkan gambaran keadaan yang ideal.

Berdasarkan hasil pengamatan dan wawancara siswa kelas VIII SMP Negeri 2 Tuntang dari segi fasilitas media pembelajaran terbatas. Media pembelajaran Pyhtagoras hanya memiliki 1 perangkat sedangkan digunakan kelas VIII lebih dari 4 kelas. Media tersebut berbentuk demonstrasi sehingga siswa hanya melihat dan memahami sehingga siswa tidak diberikan kesempatan untuk mengkonsruksi sendiri teorema Pythagoras, oleh karena itu fasilitas media pembelajaran menjadi permasalahan di kelas.

\section{B. Design (Desain)}

Berdasarkan hasil wawancara oleh guru dan juga hasil pretest, maka muncul sebuah pikiran untuk membuat media pembelajaran yang dapat menanamkan konsep teorema Pythagoras. Puzzle ini bernama PuPPy atau singkatan dari Puzzle Pembuktian Pythagoras. Media tersebut dibuat dengan bahan dasar kayu mahoni, akrilik, papan oliwod, papan triplek, lem kayu, paku, lem alteko, stiker, cet+tiner, gantungan tas, dan dempul. Untuk alat yang digunakan untuk membuatnya adalah gunting, gergaji, kater, penggaris, pensil, gergaji jiksaw, amplas dan compressor. Media tersebut terbagi atas 2 dan berikut uraian dari ke-dua bagian tersebut.

Isi

Media pembelajaran ini terdiri dari berbagai kelangkapan guna memenuhi kebutuhan pembelajaran siswa. Untuk meningkatkan kemudahan siswa dan guru dalam penggunaan media maka pada bagian isi terdiri dari 3 bagian yaitu.

a. Penentuan Bentuk Puzzle

Potongan puzzle ini terdiri dari 5 puzlle yang berbeda. Penentuan bentuk puzzle ini nantinya juga dilengkapi dengan cara pembuatan puzzle. Dari puzlle ini siswa dituntut untuk menyusun langsung puzzle agar dapat menanamkan konsep teorema Pythagoras.

b. Aturan penggunaan

Aturan penggunaan media bertujuan untuk memudahkan dalam pengoprasian media. Aturan penggunaan di letakkan di bagian pengemasan media. 
c. Instrumen evaluasi

Instrumen evaluasi dari penggunaan media ini adalah soal post tes yang tediri dari 30 soal. Soal evaluasi berbentuk pilihan ganda dan setiap 3 soal hanya menjabarkan rumus Pythagoras dari gambar yang ditanyakan.

Tampilan

a. Puzzle

Bentuk PuPPy merupakan tampilan yang nantinya akan digunkan siswa dalam menerapkan media puzzle ini. Oleh karena itu ditentukan cara penentuan warna media PuPPy. Penentuan warna media dilakukan agar dapat menarik minat siswa terhadap media puzzle PuPPy. Tak hannya menetukan warna dari potongan-potongan puzzle, penentuan warna dilakukan juga pada setiap dasaran luasan puzzle, papan puzzlenya, bahkan wadah pengemasan tak luput dari penentuan warna media.

b. Pengemasan media

Pengemasan media merupakan tempat dimana media disimpan. Pengemasan media mampu menyimpan 5 jenis potongan puzzle yang berbeda dengan dilengkapi petunjuk penggunaan dan juga cara penggunaan.

\section{Development (Mengembangkan)}

Pada tahapan ini menghasilkan sebuah media pembelajaran dengan materi teorema Pythagoras. Media pembelajaran ini berupa puzzle yang bertujuan untuk menanamkan konsep rumus Pythagoras. Pengembangan media pembelajaran ini tediri dari beberpa tahapan yang meliputi penyususnan desain media pembelajajaran kemuduan dilakukan pembuatan media puzzle, kemudian tahap penyelesaian dengan mengecek kesalahan pada media pembelajaran. Hasil dari pengembangan media puzzle sebagai berikut.

Isi

a. Penentuan Bentuk Puzzle

Penentuan pemotongan PuPPy melalui 2 tahap yakni mendesain potongan memalui kertas dan penerapannya mengguakan papan kayu. Sebelum masuk pada tahap mendesain pada kertas peneliti terlebih dahulu mengumpulkan desain-desain puzzle yang nantinya akan diteliti cara pemotongannya. Salah satu desain yang ditemukan peneliti terlihat pada Gambar1. 


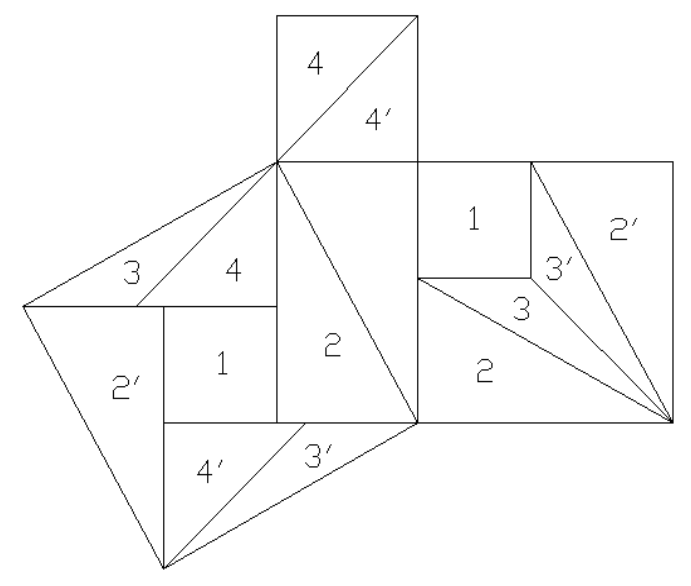

Gambar 1. Salah satu desain yang diteliti.

Setelah mengumpulkan berbagai gambar masuk pada tahap yang selanjutnya. Tahapan pertama yakni mendesain terlebih dahulu menggunakan kertas hal ini dilakukan dengan menguji cobakan potongan-potongan kertas sehingga nantinya didapat potongan yang benarbenar bisa digunakan untuk menyusun puzzle. Potongan kertas dapat dilihat pada gambar 2.

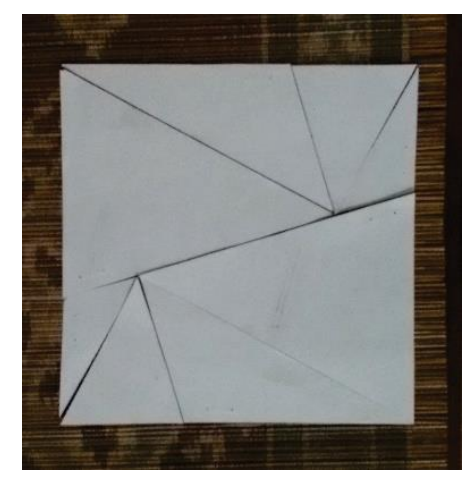

Gambar 2. Desain puzzle menggunakan kertas

Desain puzzle dijabarkan cara pembuatannya agar dapat mudah dibuat ulang. Ke-lima desain puzzle PuPPy ini juga diberikan pada setiap potongan, agar guru dapat membuatnya secara mandiri. Salah satu desain puzzle untuk cara pembuatannya dapat dilihat pada Gambar 3.

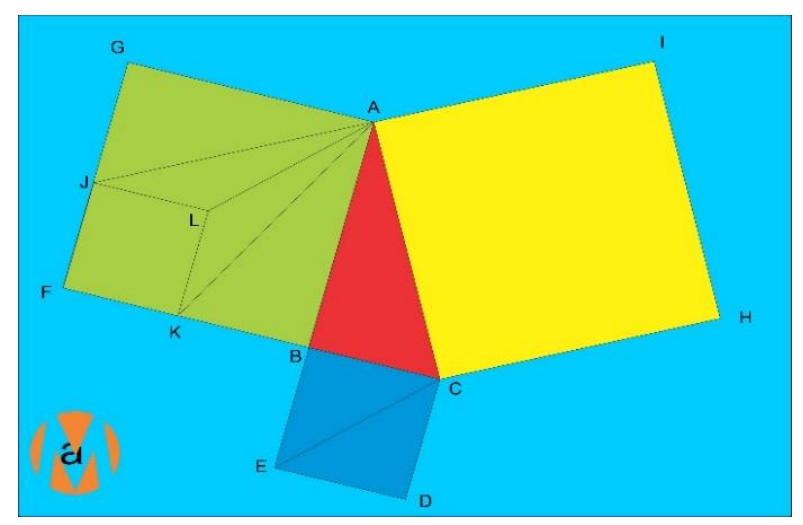

Gambar 3. Salah satu desain puzzle 
Pada gambar 3 nampak keterangan-keterangan titik-titik dari A hingga L. oleh karena itu juga terdapat keterangan cara pembuatannya yakni Buat $\Delta$ siku-siku ABC. Siku-siku di B dengan panjang $\mathrm{BC} \leq \mathrm{AB}$. Kemudian Buat persegi di setiap sisi $\Delta$ tersebut beri nama $\mathrm{ABFG}$, BCDE, ACHI. Setelah terbentuk segitiga dan setiap sisi memiliki luasan dilanjutkan dengan cara pembuatan potongan 1) Tarik diagonal CE pada persegi BCDE. 2) Perpanjang garis AI hingga memotong GF di J. 3) Tentukan titik K sehingga BK = GJ 4) Tarik garis AK. 5) Tarik garis melalui titik $\mathbf{J}$ yang $\perp \mathrm{AB}$ dan Tarik garis melalui titik $\mathrm{K}$ yang $\perp$ AG. Kedua garis tersebut berpotongan di titik L. 6) Tarik garis A ke L. setiap cara pembuatan potongan puzzle terlampirkan dibelakang unit potongan puzzle dengan cara ditempelkan dibelakangnya menggunakan stiker.

Setelah desain puzzle sudah selesai kemudian menerapkan setiap potongan puzzle pada papan kayu. Papan kayu yang digunakan untuk landasan puzzle mengunakan papan triplek, sedangkan untuk potongan puzzle menggunkan papan oliwod dipilih karena bahannya yang lebih mudah dipotong dari pada kayu-kayu yang lainnya. Media dapat dilihat pada Gambar 4.



Gambar 4. Media yang sudah dibuat menggunakan papan triplek

a. Aturan penggunaan

Aturan penggunaan dibuat untuk memudahkan dalam penggunaan media PuPPy. Aturan penggunaan di desain di bagian pengemasan media PuPPy hal ini dikarenakan agar mudah dilihat. Terdapat tujuan yakni membantu mempermudah siswa dalam memahami teorema Pythagoras. Untuk cara penggunaanya ada dua 1) pindahkan puzzle pada persegi kecil dan sedang ke persegi yang besar dan 2) pindahkan puzzle pada persegi besar ke persegi kecil dan sedang. Aturan penggunaan ini di desain menjadi satu dengan judul media dan dapat dilihat pada Gambar 5. 


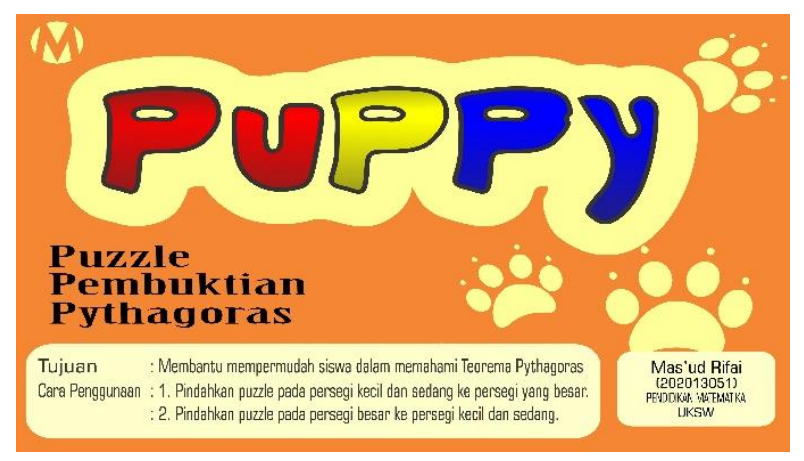

Gambar 5. Desain aturan penggunaan

Pada aturan penggunaan juga di lengkapi dengan kunci jawaban. Kunci jawaban ini berfungsi untuk membantu guru ketika melakukan permainan. Kunci jawaban diletakkan dibalik luasan persegi yang terluas. Salah satu desain pembuatan kunci jawaban puzzle dapat dilihat pada Gambar 6.

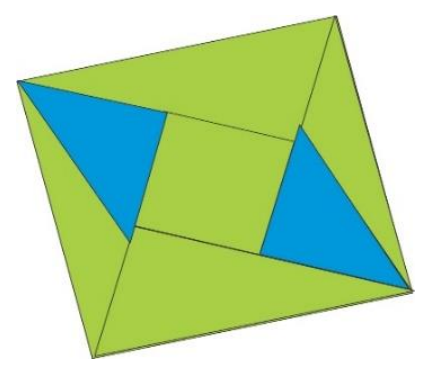

Gambar 6. Desain kunci jawaban puzzle

b. Instrumen evaluasi

Instrumen evaluasi media PuPPy dari penggunaan media ini adalah soal post tes yang tediri dari 30 soal. Soal evaluasi berbentuk pilihan ganda dan setiap 3 soal hanya menjabarkan rumus Pythagoras dari gambar yang ditanyakan. Penyusunan kisi-kisi soal yakni memhami teorema Pythagoras melalui alat peraga dan menggunakan teorema Pythagoras untuk menyelesaikan berbagai masalah. Salah satu contoh soal adalah diberi gambar segitiga sikusiku dengan keterangan panjang sisi terpendek adalah $\mathrm{x}$, panjang sisi sedang adalah y, dan panjang sisi terpanjang atau hipotenusa adalah z maka tentukan keterkaitan $\mathrm{x}, \mathrm{y}$ dan z. setiap keterangan panjang sisi-sisi segitiga dirubah-rubah dan segitiga siku-siku dibolak balik.

Tampilan

\section{c. Puzzle}

Tampilan media pembelajaran berupa 5 keping potongan puzzle dengan bentuk potongan yang berbeda. Agar lebih menarik siswa maka diberikan pewarnaan yang menarik pula. Penentuan warna ini menggunakan stiker karena lebih mudah dibuat dan lebih aman untuk siswa. Pewarnaan menggunakan cat untuk puzzle tidak digunakan karena dari seg pengeringan membutuhkan waktu lama dan juga biaya yang digunakan juga terlalu tinggi. 
Pewarnaan juga di berikan pada wadah media agar lebih menarik. Tampilan PuPPy dapat dilihat pada Gambar 7.
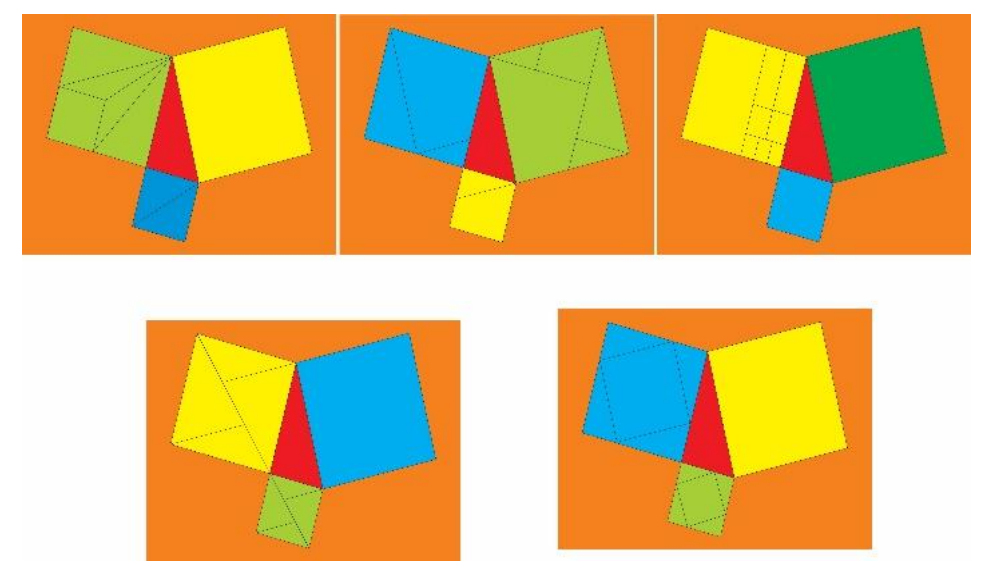

Gambar 7. tampilan media PuPPy

\section{d. Pengemasan media}

Pengemasan dibuat untuk tempat dimana media PuPPy ditempatkan agar lebih aman. Penemasan media dapat menyimpan 5 perangkat puzzle dengan setiap puzzle nya terbuat dari bahan dasar papan triplek dan kayu poliwod, ketebalan setiap puzzle nya 2,1 cm. Fungsinya adalah untuk memudahkan pembawaan dan perawatan media PuPPy. Perawatan yang dimaksudkan yakni merawat 5 perangkat puzzle dari kerusakan baik dari benturan maupun kerusakan yang lainnya. Pengemasan media PuPPy dapat dilihat pada Gambar 8.

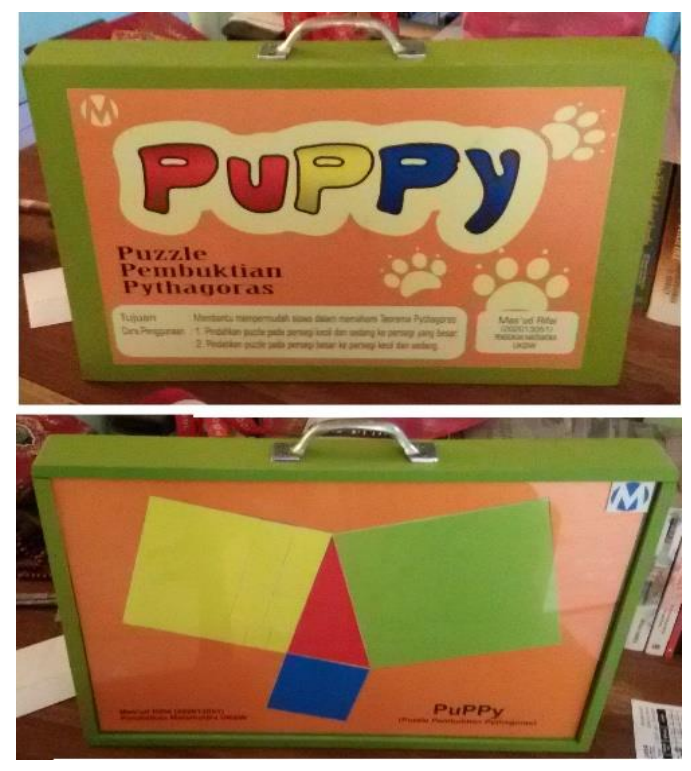

Gambar 8. Pengemasan media PuPPy

Gambar 8 terlihat pengemasan media dalam bentuk sudah jadi. Tempatnya berbentuk balok pipih yang terbuat dari kayu mahoni karena kayu lebih ringan daripada kayu-kayu yang lain. Dilengkapi dengan tutup yang terbuat dari akrilik yang tembus pandang sehingga media puzzle didalamnya dapat nampak dari luar ketika dilihat. Bagian luar dari pengemasan media PuPPy juga terdapat pegangan tangan agar mudah dibawa dan dipindahkan dan terdapat 
keterangan cara penggunaan dan tujuan dari media PuPPy yang tertera di bagian balik dari tutup wadah media. Pewarnaan pada pengemasan menggunakan pewarna kayu karena lebih mudah dalam pewarnaan dan diharapkan menarik untuk dibawa.

C. Implementation (Implementasi)

Pada tahap implementasi merupakan langkah pengujian media pembelajaran guna mengetahui sudah layak atau tidaknya untuk digunakan. Pada tahap ini media pembelajaran ini di uji dalam tiga tahap yaitu uji validasi, kepraktisan dan keefektifan. Berikut uraian masing tahap.

a. Uji Validasi Media Pembelajaran

Validasi ahli adalah tahap untuk validasi media pembelajaran oleh validator. MMedia PuPPy telah divalidasi dengan istrumen yang terbagi atas 2 aspek yakni media dan materi, untuk indikator sebanyak 28 yakni media 13 indikator dan materi 15 indikator. Validasi dilaksanakan dengan tujuan agar media yang telah dikembangkan mendapatkan saran dari validator dengan saran pada Tabel 5. Daftar validator media pembelajaran pada Tabel 4.

Tabel 4. Daftar Validator

\begin{tabular}{|c|c|c|}
\hline No & Validator & Keterangan \\
\hline 1. & Yustinus, M.Pd. (Validator 1) & Guru serta dosen Pendidikan Matematika \\
\hline 2. & Marcus Subagya (Validator 2) & Dosen Pendidikan Matematika \\
\hline
\end{tabular}

Tabel 5. kritik dan saran dari validator

\begin{tabular}{|l|ll|l|l|}
\hline Validator & \multicolumn{3}{|c|}{ Kritik dan Saran } & \multicolumn{1}{c|}{ Tindak Lanjut } \\
\hline \multirow{4}{*}{1} & $\begin{array}{l}\text { Berikan warna pada setiap tempat } \\
\text { luasan puzzle sesuai } \\
\text { puzzlenya, patenkan segitiga siku- } \\
\text { siku merah agar }\end{array}$ & $\begin{array}{l}\text { Mematenkan segitiga siku-siku } \\
\text { merah dengan cara menempel, } \\
\text { membingungkan siswa. Warna dari } \\
\text { potongan puzzle jangan diberi warna } \\
\text { yang berbeda-beda. }\end{array}$ & $\begin{array}{l}\text { luasan puzzle yang sesuai } \\
\text { dengan puzzlenya. Memberikan } \\
\text { warna yang pasti. }\end{array}$ \\
\hline \multirow{2}{*}{$\begin{array}{l}\text { Puzzle agar lebih dirapikan dan } \\
\text { mudah diambil } \\
\text { digunakan. ketika akan }\end{array}$} & $\begin{array}{l}\text { Untuk penempelan stiker lebih } \\
\text { berhati-hati agar rapi, dan } \\
\text { potongan puzzle agak diberi } \\
\text { longer suapaya ketika diambil } \\
\text { mudah. }\end{array}$ \\
\hline
\end{tabular}

Setelah mendapatkan kritik dan saran dari validator, kemudian dilakukan pembenahan terhadap media PuPPy. Dengan adanya kritik dan saran pada PuPPy terdapat beberapa perubahan. Dintaranya menjadikan warna paten di setiap luasan tidak berwarna-warni di setiap luasan, mematenkan segitiga siku-siku merah, pemberian warna pada setiap tempat 

luasan puzzle, dan memberikan ruang lebih longgar agar puzzle mudah diambil ketika digunakan. Adapun hasil pembenahan dapat dilihat pada Gambar 9.
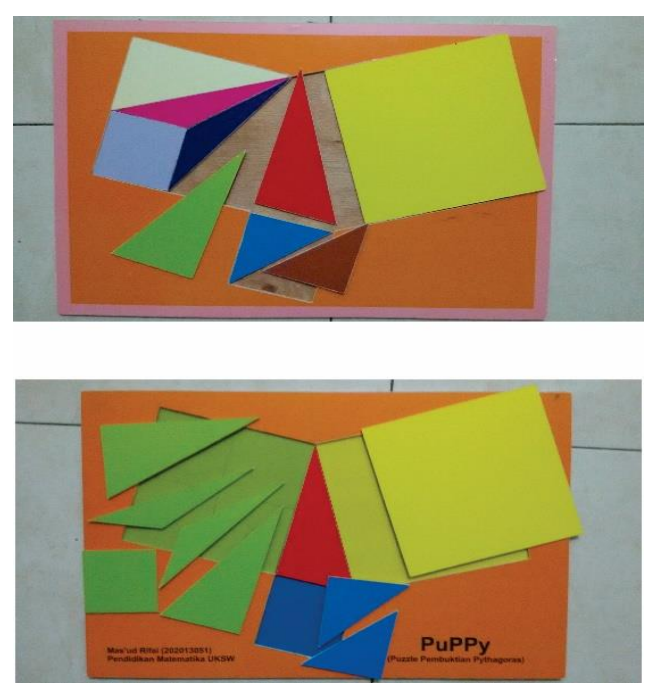

Gambar 9. Setelah melakukan pembenahan

Adapun rekapitulasi hasil validasu dapat dilihat pada Tabel 6. Terlihat bahwa media pembelajaran ini termasuk kriteria sangat baik dengan persentase $94,61 \%$ pada aspek media sedangankan dari aspek materi persentase yang didapat yakni 91,33\% sehingga dikategorikan sangat baik. Pada tahap validasi terkhir inilah validator menyatakan bahwa media PuPPy layak untuk digunakan.

Tabel 6. Hasil validasi setelah mendapatkan kritik dan saran

\begin{tabular}{|c|c|c|c|c|}
\hline \multirow[b]{2}{*}{ VALIDATOR } & \multicolumn{2}{|c|}{ MEDIA } & \multicolumn{2}{|c|}{ MATERI } \\
\hline & \begin{tabular}{|l} 
DESAIN \\
MEDIA
\end{tabular} & TAMPILAN & $\begin{array}{c}\text { DESAIN } \\
\text { PEMBELAJARAN }\end{array}$ & TAMPILAN \\
\hline $\begin{array}{l}\text { Marcus subagya } \\
\text { M.Pd }\end{array}$ & 34 & 30 & 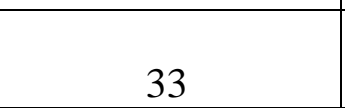 & 38 \\
\hline Yustinus, M.Pd. & 34 & 29 & 30 & 36 \\
\hline \multirow{2}{*}{$\begin{array}{c}\text { Sub Jumlah } \\
\text { Sub Rata-rata }\end{array}$} & 64 & 59 & 63 & 74 \\
\hline & 32 & 29,5 & 31,5 & 37 \\
\hline Total Max & \multicolumn{2}{|r|}{130} & \multicolumn{2}{|l|}{150} \\
\hline Total & \multicolumn{2}{|r|}{123} & \multicolumn{2}{|l|}{137} \\
\hline Rata-rata & \multicolumn{2}{|r|}{61,5} & \multicolumn{2}{|l|}{68,5} \\
\hline \multicolumn{2}{|c|}{$\begin{array}{c}\text { Persentase } \\
\text { Ketegori }\end{array}$} & $\begin{array}{c}94.61 \% \\
\text { Sangat Baik }\end{array}$ & \multicolumn{2}{|c|}{$\begin{array}{c}91,33 . \% \\
\text { Sangat Baik }\end{array}$} \\
\hline
\end{tabular}

b. Uji Kepraktisan

Media PuPPy telah di uji cobakan terhadap 28 siswa SMP Negeri 2 Tuntang Kabupaten Semarang selama 2 jam pelajaran. Adapun hasil penilaian kepraktisan penggunaan media PuPPy dilakukan oleh Ibu Andri, S.Pd dan Nugraheni Cahyaningrum, M.Pd sebagai Guru SMP N 2 Tuntang Kabupaten Semarang dengan rekapitulasi hasil yang dapat dilihat pada Tabel 6. 
Tabel 6. Hasil uji kepraktisan oleh guru

\begin{tabular}{|c|l|l|l|}
\hline \multirow{2}{*}{ NAMA } & \multirow{2}{*}{ KETERANGAN } & \multicolumn{2}{|c|}{ ASPEK } \\
\cline { 3 - 4 } & & \multicolumn{1}{|c|}{ Materi } & \multicolumn{1}{|c|}{ Media } \\
\hline \hline \multicolumn{1}{|c|}{ Andri, S.Pd. } & Guru Matematika & 35 & 45 \\
\cline { 3 - 4 } $\begin{array}{c}\text { Nugraheni } \\
\text { Cahyaningrum, } \\
\text { M.Pd }\end{array}$ & SMP 2 Tuntang & 31 & 41 \\
\hline \hline $\begin{array}{l}\text { Sub Jumlah } \\
\text { Sub Rata-rata }\end{array}$ & & \\
Total Max & 66 & 86 \\
Total & & 33 & 43 \\
Rata-rata & 160 & \\
Persentase & & 152 \\
Ketegori
\end{tabular}

Berdasarkan hasil anaisis dari data kepraktisan media terdapat rata-rata sebesar 76 dan persentase 95\% media dapat digolongkan pada kategori sangat baik. Oleh karena itu media praktis digunkana pada siswa kelas VIII SMP untuk mengkonstruksi rumus Pythagoras.

c. Uji Keefektifan

Selatah siswa menggunkan media PuPPy siswa diberikan posttest yang sebelumnya siswa sudah mengerjakan pretest dan dilajutkan dengan mengisi respon lembar pendapat siswa. Instrument pendapat siswa terdiri dari 5 indikator.

Pendapat yang diperoleh dari respon siswa, bahwa media pembelajaran PuPPy (Puzzle Pembuktian Pythagoras) menarik untuk sarana pembelajaran. Siswa merasa tertantang untuk mencoba media yang memiliki potongan puzzle yang berbeda-beda. Penggunaan media PuPPy sangat mudah karena hanya memindahkan potongan-potongan puzzle saja. Siswa juga merasa senang karena dengan bermain mereka juga bias sekaligus belajar. Siswa juga mengatakan dengan ppraktek langsung seperti ini siswa lebih mudah memahami rumus Pythagoras.

Uji keefektian dlakukan dikelas VIII D SMP Negeri 2 Tuntag Kabupaten Semarang. Jumlah disiswanya adalah 28 siswa. Rata-rata nilai siswa setelah melakukan uji coba tes dengan materi yang telah diajarkan sebesar 36 dengan nilai tertinggi 76,6 dan yang terendah 16,6. Kemudian siswa diberikan soal posttest untuk mengetahui tinngkat kemajuan belajar siswa sebelum dan sesudah menggunakan media PuPPy. Soal terdiri dari 30 soal uraian setiap 3 soal siswa diminta untuk menjabarkan keterkaitan dari sebuah segitiga siku-siku dengan panjang setia sisi-sisi yang berbeda-beda. Soal-soal ini dikerjakan siswa sekitar 40 menit dengan kata lain 1 jam pelajaran. Setelah melakukan posttest menunjukkan hasil rata-rata 94,61 dengan persentase ketuntasan 82,14\% dengan jumlah siswa sebanyak 23 dan persentase 
siswa yang tidak tuntas sebesar 17,59\% sebanyak 5 siswa. Adapun hasil dari pretest dan posttest dapat dilihat pada tabel 7.

Tabel 7. Hasil pretest dan Posttest

\begin{tabular}{|c|c|c|c|c|c|c|c|c|}
\hline \multirow{2}{*}{ Test } & \multirow{2}{*}{$\begin{array}{c}\text { Jml } \\
\text { Sampel }\end{array}$} & \multicolumn{2}{|c|}{ Tuntas } & \multicolumn{2}{|c|}{$\begin{array}{l}\text { Belum } \\
\text { Tuntas }\end{array}$} & \multirow{2}{*}{$\begin{array}{c}\text { Rata- } \\
\text { rata }\end{array}$} & \multicolumn{2}{|c|}{ Nilai } \\
\hline & & $\mathrm{Jml}$ & $\%$ & $\mathrm{Jml}$ & $\%$ & & $\operatorname{Max}$ & Min \\
\hline Pretest & \multirow[t]{2}{*}{28} & 2 & $7,1 \%$ & 26 & $92,86 \%$ & 42,93 & 76,6 & 16,6 \\
\hline Posttest & & 23 & $82,1 \%$ & 5 & $17,59 \%$ & 86,76 & 100 & 53,6 \\
\hline
\end{tabular}

Didapatkan data hasil pretest dan posttes pada tabel 8.

Tabel 8. Data nilai postes dan pretest

\begin{tabular}{|l|c|c|c|c|}
\hline \multirow{2}{*}{ VIII D SMP } & \multicolumn{2}{|c|}{ Pretest } & \multicolumn{2}{c|}{ Posttest } \\
\cline { 2 - 5 } & Jumlah Skor & Rata-rata & Jumlah Skor & Rata-rata \\
\cline { 2 - 5 } & $1.202,3$ & 42,93 & $2.342,6$ & 86,76 \\
\hline
\end{tabular}

Setelah diperoleh data hasil belajar pretest dan posttest siswa, kemudian dianalisis signifikansi peningkatan dengan rumus $\mathrm{N}$-Gain berikut

$$
\begin{gathered}
N-\text { Gain }=\frac{\text { skor posttest }- \text { skor pretest }}{\text { skor maksimum }- \text { skor pretest }} \\
N \text { Gain }=\frac{2.342,6-1.202,3}{2.800-1.202,3}
\end{gathered}
$$

$N$ Gain $=0,7137$

Berdasarkan perhitungan menggunakan rumus $\mathrm{N}$-Gain didapatkan hasil belajar siswa kelas VIII D SMP Negeri 2 Tuntang mengalami peningkatan 0,7137 yang artinya dalam peningkatan tinggi. Hasil tersebut menunjukkan bahwa media PuPPy efektif bagi siswa kelas VIII D SMP Negeri 2 Tuntang kareba terjadi peningkatan tinggi setelah penggunaan.

Adapun respon siswa setelah menggunakan media dapat dilihat pada Tabel 9. Keterangan tabel untuk pertanyaan 1 disingkat P1 dan seterusnya. Untuk setiap pertanyaanya yakni 1) Aturan peggunaaan media ini mudah saya pahami, 2) Media ini bermanfaat bagi saya, 3) Media ini membantu saya memahami rumus Pythagoras, 4) Media ini menarik bagi saya dan 5) Saya tertantang untuk menggunakan media ini. Respon siswa dapat dikategorikan 
sangat senang, setuju dan cukup. Adapun hasil rekapitulasi hasil respon siswa terhadap media PuPPy dapat dilihat pada Tabel 9.

Tabel 9. Respon siswa terhadap media PuPPy

\begin{tabular}{|c|c|c|c|c|c|}
\hline $\begin{array}{c}\text { Rertannyaan } \\
\text { Respon } \\
\text { Sangat Setuju }\end{array}$ & $\mathrm{P} 1$ & $\mathrm{P} 2$ & $\mathrm{P} 3$ & $\mathrm{P} 4$ & $\mathrm{P} 5$ \\
\hline $\begin{array}{c}\text { - } \\
0 \\
\text { Setuju }\end{array}$ & $28,57 \%$ & $50 \%$ & $35,72 \%$ & $21,43 \%$ & $28,57 \%$ \\
\hline $\begin{array}{c}-0 \\
0\end{array}$ & $3,57 \%$ & - & $3,57 \%$ & - & $3,57 \%$ \\
\hline $\begin{array}{c}\text { Cukup } \\
\text { total }\end{array}$ & $100 \%$ & $100 \%$ & $100 \%$ & $100 \%$ & $100 \%$ \\
\hline
\end{tabular}

D. Evaluation (evaluasi)

Pada tahap ini dilakukan tiga uji yakni kevalidan, kepraktisan dan keefektifan. Hasil dari evaluasi dari ketiga hal tersebut dijabarkan sebagai berikut.

1) Analisis data uji validasi

Analisis kevalidan media dilakukan dua tahap. Tahap pertama validasi dilakukan untuk mengumpulkan kritik dan saran dari validator guna untuk memperbaiki perangkat PuPPy. Tahap kedua yakni penilaian akhir dari media PuPPy setelah mendapat kritik dan saran dari validator. Oleh karena itu analisis kevalidan terdiri dari dua aspek yaitu aspek materi dan aspek tampilan. Berikut penjelasan pada masing-masing aspek.

a) Aspek media

Lembar penilaian aspek media terdiri dari 13 indikator yakni 7 indikator untuk desain media dan 6 indikator untuk tampilan media. Berdasarkan peilaian validator pada tahap 1 validator menambahkan berbagai kritik seperti menambah warna, mematenkan segitiga sikusiku. Setelah menindaklanjuti pada tahap 1 maka diperoleh skor rata-rata 61,5 dengan persentase 94,61\% dengan kategori sangat baik. Berdasarkan 13 indikator tersebut dapat disimpulkan bahwa media PuPPy dapat digunakan untuk mengkonstruksi pemahaman siswa tentang rumus Pythagoras. Media ini juga tepat digunakan untuk mencapai tujuan yang diinginkan serta efesien dalam penggunaannya. Media pembelajaran memiliki warna yang menarik, kemasan yang memudahkan guru untuk menyimpan dan membawa. 
b) Aspek materi

Lembar penilaian aspek materi terdiri dari 15 indikator yakni 7 indikator untuk desain dan 6 indikator untuk tampilan. Setelah melakukan validasi pada tahap pertama maka diperoleh penilaian pada tahap ke-dua diperoleh skor rata-rata 68,5 dengan persentase $91,33 \%$ dengan kategori sangat baik. Materi yang dituju pada media PuPPy sangatlah tepat yakni menanamkan konsep Pythagoras agar siswa tidak terbolak balik dalam penerapannya.

Berdasarkan hasil validasi tahap terakhir menunjukkan bahwa aspek media memperoleh persentase $94,61 \%$ dan aspek materi $91,38 \% \geq 62 \%$, maka H0 ditolak sehingga dapat disimpulkan media pembelajaran valid, karena melebihi kriteria cukup baik dan masuk pada kriteria sangat baik.

2) Analisis data uji kepraktisan

Kepraktisan media pembelajaran ditentukan oleh hasil analisis data keprakisan menggunakan lembar instrument kepraktisan media pembelajaran. Responden dari instrumen kepraktisan adalah dua guru matematika SMP Negeri 2 Tuntang Kabupaten Semarang. Adapun hasil analisis data diperoleh rata-rata 76 dengan persentase 95,5\% termasuk dalam kategori sangat baik. Nilai uji kepraktisan menghasilkan $\mathrm{P}(\mathrm{s}) \geq 62 \%$ sehingga disimpulkan bahwa media PuPPy ini digolongkan dalam kategori praktis untuk digunakan siswa maupun guru. Media ini praktis dalam artian mudah dalam perawatan, mudah dalam penggunaan, dan juga memiliki tujuan pembelajaran yang jelas.

3) Analisis data uji keefektifan

a) Hasil uji lembar pendapat siswa

Berdasarkan hasil lembar pendapat siswa, siswa memberikan repon positif terhadap media karena mereka cenderung berminat belajar sambil bermain. Dapat dilihat pada persentase respon pendapat siswa terhadap media untuk aturan penggunaan siswa merasa sangat puas 28,57\%, setuju 67, 86\% dan cukup 3,57\%. Adapun persentase media ini bermanfaat bagi saya, siswa merasa sangat puas $50 \%$ dan setuju 50\%. Adapun media ini membantu saya memahami rumus Pythagoras, siswa merasa sangat puas 35,72\%, setuju $60,71 \%$ dan cukup $3,57 \%$. Adapun media ini menarik bagi saya, respon siswa terhadap media ini sangat setuju sebesar 21,43\% dan setuju 78,57\%. Dan adapun saya tertantang untuk menggunakan media ini, sangat setuju $28,57 \%$, setuju $67,86 \%$ dan cukup 3,57\%. Dapat disimpulkan dari respon siswa siswa cukup antusias dalam menggunakan media PuPPy dengan respon setuju melibihi $50 \%$.

c) Hasil uji N-Gain

Hasil uji kemampuan siswa berdasarkan pretest dan posttest dianalisis kemudian dihitung peningkatannya menggunakan rumus N-Gain. Berdasarkan perhitungan rumus N- 
Gain kelas VIII D SMP Negeri 2 Tuntang mengalami peningkatan sebesar 0,71 yang termasuk dalam kategori peningkatan tinggi. Dapat dismpulkan bahwa media PuPPy efektif digunakan sebagai media pembelajaran.

\section{Kesimpulan}

Produk yang dihasilkan pada media ini adalah PuPPy yakni Puzzle Pembuktian Pythagoras. Media ini disiapkan untuk memenuhi kebutuham pembelajran materi Pythagoras. Hasil penelitian menyatakan bahwa media PuPPy yang dikembangkan berdasarkan lima langkah model ADDIE valid, praktis dan efektif digunakan untuk mengkonstruksi siswa dalam belajar Pythagoras. Hasil validasi media menunjukkan skor rata-rata 61,5 $(94,61 \%)$ dengan kategori sangat baik dan hasil validasi materi menunjukkan skor rata-rata 68,5 $(91,33 \%)$ dikategorikan sangat baik. Hasil analisis lembar kepraktisan menunjukkan skor ratarata 76 dengan persentase $95,5 \%$ dikategorikan sangat baik. Siswa yang menggunakan media PuPPy memberikan respon positif terhadap media PuPPy. Selain itu melalui perhitungan NGain terdapat peningkatan sebesar 0,71 sehingga dapat dikategorikan dalam peningkatan yang tinggi.

Media pembelajaran ini digunakan untuk menanamkan konsep siswa terhadap teorema Pythagoras. Tidak hanya siswanya saja yang diberikan keleluasaan di dalam menggunakan media artinya belajar sambal bermain, guru juga diberi kemudahan untuk dapat membuat sendiri media dengan cara dapat menentukan potongan-potongan puzzle pada cara penggunaan yang telah disediakan. Harapan pada pengambangan media ini adalah, dapat dikembangkan lebih banyak tentang potongan-potongan puzzle yang ada dikarenakan keerbatasan peneliti, peneliti hanya dapat menyajikan 5 potongan puzzle yang berbeda. Oleh karena itu diharapkan media PuPPy dapat diteliti lebih banyak untuk jenis farina potonganpotongan yang berbeda-beda.

\section{Pustaka}

Adinawan, Sugiono. 2006. MATEMATIKA SMP Jilid 2A Kelas VIII. Jakarta. PT. Gelora Aksara Pratama

Arif S. Sadiman, dkk. 2009. Media Pendidikan, Pengertian, Pengembangan, dan Pemanfaatanya. Jakarta: Rajawali Press

Arsyad Azhar. 2006. Media Pembelajaran. Jakarta, PT. RajaGrafindo Persada

Heruman. 2013. Model Pembelajaran maematika di Sekolah Dasar. Bandung: Remaja Rosdakarya

Husain Tampomas. 2005. Matematika 2 untuk SMP Kelas VIII. Yudistira: Jakarta

Ismatul Khasanah. 2013. Pembelajaran Logika Matematika Anak Usia Dini (Usia 4-5 Tahun) di TK IKAL BULOG Jakarta Timur. Jurnal Penelitian PAUDIA, Volume2No.1 diakses 
melalui http://download.portalgaruda.org/article.php?article=88240\&val=530pada tanggal 27 Juni 2016 pukul 10.38 WIB.

Katz, Victor J. 2009. A History of Mathematics An Introduction. University of the District of Columbia

Latifah Puji. 2012. Pengembangan Media Pembelajaran dengan Multimedia Interaktif Menggunakan Adobe Flash CS3 untuk Memfasilitasi Kemampuan Pemecahan Masalah pada Pembelajaran Matemaatika SMP Kelas VIII. Skripsi pada program studi pendidikan matematika Fakultas Sains dan Teknologi Universitas Negri Sunan Kalijaga, Yogyakarta. Diakses melalui: https://www.google.co.id/\#q=Latifah+Puji+Astuti+(2012)+dengan+judul+\%E2\%80\%9CPengemb angan+Media+Pembelajaran+dengan+Multimedia+Interaktif+Menggunakan+Adobe+Flash+CS3+ untuk+Memfasilitasi+Kemampuan+Pemecahan+Masalah+pada+Pembelajaran+Matemaatika+SM $\mathrm{P}+$ Kelas+VIII+

Paul Suparno. (1997). Filsafat Konstruktivisme dalam Pendidikan. KANISIUS: Yogyakarta

Musfiqon. 2012. Pengembangan Media dan Sumber Pembelajaran. Jakarta: PT. Prestasi Pustakaraya

Tingkatan memorisasi oleh teori Eddgar Dale diakses melalui: copyright dit.akademik.ditjen.dikti pada tanggal 27 Juni 2016 pukul 21.28 WIB.

Rusman. 2012. Belajar dan Pembelajaran Berbasis Komputer. Bandung: Rajawali Press

Pribadi, Benny A. 2009. Model Desain Sistem Pembelajaran. Jakarta: Dian Rakyat

Trianto. 2015. Mendesain Model Pembelajaran INOVATIF, PROGRESIF, DAN KONTEKSTUAL. Jakarta: PT Kharisma Putra Utama

Suparto. 2006. Upaya Meningkatkan Prestasi Belajar Sisa KelasVIIIA MTs Nurul Ulum Jembayat Kecamatan Margasari Kabupaten Tegal Tahun Pelajaran 2005/2006 pada Pokok Bahasan teorema Pythagoras Melalui Penggunaan Alat Peraga Model Pythagoras. Skripsi pada Fakultas Matematika dan Ilmu Pengetahuan Alam Universitas Negeri Semarang. Diakses melalui: https://www.google.co.id/\#q=yang+berjudul+\%E2\%80\%9CUpaya+meningkatkan+prestasi+belaja $\mathrm{r}+$ siswa+kelas+VIII+MTs+Nurul+Ulum+Jembayat+Kecamatan+Margasari+Kabupaten+Tegal+Ta hun+Pelajaran+2005/2006+pada+Pokok+Bahasan+Teorema+Pythagoras+Melalui+Penggunaan+ Alat+Peraga+Model+Pythagoras(suparno+)

Sugiyono. 2011. Metode Penelitian Pendidikan: pendekatan kuantitatif, kualitatif dan R\&D. Bandung: Alfabeta

Untung T, dkk. 2008. Permasalahan Pembelajaran Geometri Datar SMP dan Alternatif Pemecahannya. Yogyakarta: DEPARTEMEN PENDIDIKAN NASIONAL

Vernanda, Yunus. 2013. Meningkatkan Kemampuan Mengenal Huruf Vocal Melalui Media PUZZLE bagi Anak Kesulitan Belajar Kelas II SDN 18 Koto Luar. Vol 2 No 3 September 2013, halaman: 692-704. Di akses melalui: http://ejournal.unp.ac.id/index.php/jupekhu 